\title{
Ovine Jaagziekte Virus
}

National Cancer Institute

\section{Source}

National Cancer Institute. Ovine laagziekte Virus. NCI Thesaurus. Code C14318.

A herpesvirus of sheep associated with pulmonary adenomatosis 